\title{
The Effects of Stunting And Psychosocial Stimulus On The Development of Children Between The Age Of 2- 6 Years Old
}

\author{
Candra Dewinataningtyas*, Dian Kumalasari \\ Bhakti Wiyata Institute of Health Science of Kediri, Indonesia \\ *candra.nataningtyas@iik.ac.id
}

\begin{abstract}
Even as we reach a globalized era, there are issues pertaining nutrition that significantly plague the quality of human resource. One of which is the high rate of stunting or toddlers with delayed physical development. This research aims to analyze the effects of stunting and psychosocial stimulation on the development of children between the ages of 2-6 years old. This is a observational analytical research with a case control approach, on a sample of 60 children of 2-6 years old, which consists of 41 children with stunting as a case sample (19 children categorized as short and 22 children categorized as very short) and 19 children without stunting or in a normal condition as a control sample, selected through purposive sampling. The degree of stunting is assessed using Z-score indicator, calculating children physical height per age (H/A), which is then classified according to WHO standard. Meanwhile, for psychosocial stimulation, it is obtained through questionnaire filled by parents or caregivers. Children development is measured using Pre-Screening Developmental Questionnaire (Kuesioner Pra Skrining Perkembangan or KPSP). Data is analyzed using chi-square test and logistic regression. Statistically speaking, the sig. value according to chi-square test is 0,000 . This value is smaller than 0,05 , which can be concluded that stunting and psychosocial stimulus significantly affect child development. The result of multivariate test indicates that stunting and psychosocial stimulation variables have a significant influence on the development of a child $(p<0,05)$. This research concludes that both stunting and psychosocial stimulation have a significant influence on the development of a child between the age of 2-6 years old.
\end{abstract}

Keywords : Stunting, Psychosocial Stimulation, Child Development

Received June 8, 2020; Revised July 28, 2020; Accepted September 10, 2020 


\section{STRADA Jurnal Ilmiah Kesehatan}

DOI: $10.30994 /$ sjik.v9i2.396

ISSN: 2252-3847 (print); 2614-350X (online)

Vol.9 No.2 November 2020 Page.906-916

\section{BACKGROUND}

Worldwide data in 2018 indicates that many children under 5 years old experience stunted growth and development, especially in Low- and Middle-Income Countries or LMIC. This issue ties in intricately with the impaired cognitive development in children (Alam, Ashrafaul, et. al., 2020). Similar health problem, one that Indonesia has to be wary of, is stunting cases in toddlers. Data regarding the prevalence of stunting in toddlers collected by World Health Organization (WHO) released in 2018 reports that Indonesia is one of the third world nation with the highest prevalence of stunting in South-East Asian Region with 36,4\%. (Centre for Data and Information of the Ministry of Health, 2018). This indicates that Indonesia sees the prevalence of stunting cases above 20\%, meaning it has not met WHO target, which is below 20\% (Teja, 2019). In Sustainable Development Goals (SDG), one of the goals in health sector regarding community nutrition improvement target by 2030 is to eliminate all forms of malnutrition, including conforming to international target for stunting by 2025. (Rahmawati, et. al, 2018). Stunting or growth impairment is a condition illustrating malnourishment status that is chronic to the development age and the early development of children as presented with a standard deviation score of less than minus two on the z-score value of physical height-to-age ratio, according to WHO growth standard. (Ni'mah, 2015).

Child development period, especially on the first three years, iscritical (Georgieff MK, 2007). This period of development sees a higher risk of malnutrition. Chronic malnutrition is correlated with the development of a child's brain. The condition, stunting, happens when the neural cells, especially in the cerebellum which is the epicenter of motor coordination, experience delayed maturity. Several studies indicate that stunting corresponds with the motor development in children. (Hizni, 2009. Chang SM, 2010). Motor development is a crucial development aspect as it is strongly related with other development aspects, specifically cognitive development. Cognitive development indirectly influences the quality of Human Resources (HR). (Gamayanti IL, 2010). One of the most important elements in preventing stunting is parental interaction. Mother-child interaction is the integral element in the course of child development (GranthamMcGregor SM, 2007). This corresponds with the parent's ability to facilitate and support the growth and development of a child (Santos DN, 2008). Playing and learning indirectly encourage or stimulate toddlers to grow consistent with his/her motor development stage. Stimulation is one of the psychological factors sparking a child's basic ability to grow in the most optimal manner(Republic of Indonesia Ministry of Health, 2006).

Studies conducted on animals establish that stimulation can improve dendritic branching and the number of dendrites, thus improving the dendrodendritic connection. Dendrodendritic connection is responsible to the motor and cognitive abilities. The more dendrodendritic connections there are, the better motor and cognitive abilities are (Restivo L. et al., 2005 andPapalia DE. et al. 2008). Research on child stunting in Jamaica indicates that stimulation has a greater effect on child motor development than nutrition, whereby children with stunting sees an increased score on mental and motor development at the same level with normal children after receiving stimulation and supplements (Walker WA. et. al., 2003).

Kediri Municipality of East Java is one of the 60 regencies or municipalities with a high rate of stunting in 2019. According to the General Health Research (Riset Kesehatan Dasar or Riskesdas) in 2013, the prevalence of stunting in toddlers in Kediri is at a high 35,07\%. Correspondingly, the data warrants the necessity to conduct a research regarding the impacts of stunting and psychosocial stimulation on the development of children between 


\section{STRADA Jurnal Ilmiah Kesehatan}

DOI: $10.30994 /$ sjik.v9i2.396

ISSN: 2252-3847 (print); 2614-350X (online)

Vol.9 No.2 November 2020 Page.906-916

the ages of $2-6$ in the municipality of Kediri, East Java. The result of this study is expected to shed some enlightening information regarding how integral it is to prevent stunting and to provide psychosocial stimulation as early as possible, in an attempt to achieve the optimal motor development and quality human resources in the long run.

\section{METHOD}

This is an observational analytical research with a case control approach. The case population of this study is children of 2-6 years old with stunting, while the control population is children of 2-6 years old without stunting. This study took place in the Municipality of Kediri between July-August 2020. Sampling technique used is a purposive sampling method, with a population of 60 children between the age of 2-6 years old, consisting of 41 children with stunting as a case sample (19 children categorized as short and 22 children categorized as very short) and 19 children without stunting or in a normal condition as a control sample, selected through purposive sampling.

Free variables in this study are stunting and psychosocial stimulation. On the other hand, bound variable shall be the development of children between the ages of 2-6 years old. Stunting is defined as the measurement of nutritional status based on physical body height index $(\mathrm{BH})$ per age $(\mathrm{A})$ as referred to in WHO standard and anthropometry standard of child health of the Ministry of Health of Republic of Indonesia 2011. The following is the category of stunting: very short (z-score $<-3 \mathrm{SD}$ ), short (z-score 3SD to z-score < -2 SD), normal (z-score $\geq-2,0$ to 2 SD). Psychosocial stimulation data is obtained using questionnaire filled by parents or caregivers. Child development is measured using PreScreening Development Questionnaire (KPSP), measuring gross motor skills, fine motor skills, socialization-independence, and speech-language.

After obtaining research permit, data collection is conducted by interviewing parents and caregivers, asking them to fill the questionnaire and gauging child development. Data collected involve stunting, psychosocial stimulation, and child development measurement data to be further scrutinized using univariate analysis in order to shed detailed information regarding the frequency distribution of stunting and psychosocial stimulation. Bivariate test is conducted to analyze the correlation between two variables. This analysis implements cross-tabulation and chi-square test. Multivariate test in this study uses logistic regression test. Logistic regression analysis is used to determine the effect free variables have on bound variables. In this case, the effects stunting and psychosocial stimulation have on child development.

\section{RESULTS}

The Effects of Stunting and Psychosocial Stimulation on the Development of Children between the Ages of 2-6 Years Old.

1. Univariate Analysis.

Table 1.1 Stunting Frequency Distribution

\begin{tabular}{lcc}
\hline \multicolumn{1}{c}{ Stunting } & Frequency & Percentage \\
\hline Very Short & 19 & $31,7 \%$ \\
\hline Short & 22 & $36,7 \%$ \\
\hline Normal & 19 & $31,7 \%$ \\
\hline Total & 60 & $100 \%$ \\
\hline
\end{tabular}




\section{STRADA Jurnal Ilmiah Kesehatan}

DOI: $10.30994 /$ sjik.v9i2.396

ISSN: 2252-3847 (print); 2614-350X (online)

Vol.9 No.2 November 2020 Page.906-916

Table 1. Provides information on stunting frequency distribution. 19 respondent children $(31,7 \%)$ in this study are categorized as normal. There are 19 respondent children $(31,7 \%)$ categorized as very short and 22 children categorized as short $(36,7 \%)$.

Table 1.2 Psychosocial Stimulation Frequency Distribution

\begin{tabular}{lcc}
\hline Psychosocial & Frequency & Percentage \\
\hline Rarely & 9 & $14 \%$ \\
\hline Occasionally & 14 & $23,3 \%$ \\
\hline Often & 20 & $33,3 \%$ \\
\hline Always & 17 & $28,3 \%$ \\
\hline Total & 60 & $100 \%$ \\
\hline
\end{tabular}

Table 2 Provides information on the frequency distribution of psychosocial stimulation. There are 20 respondent children $(33,3 \%)$ who often receive psychosocial stimulation. Meanwhile, there are 9 respondent children (14\%) who rarely receive psychosocial stimulation.

\section{Bivariate Test}

Bivariate test is conducted to analyze the correlation between two variables. This analysis implements cross-tabulation and chi-square test. Cross tabulation between stunting and child development will be presented in the table 3 below:

Table 2.1 Cross tabulation between stunting and child development

\begin{tabular}{llcccc} 
& & \multicolumn{3}{c}{ Development } & \\
\cline { 3 - 5 } Stunting & Very Short & 13 & 6 & 0 & 19 \\
\cline { 2 - 5 } & Short & 3 & 14 & 5 & 22 \\
\cline { 2 - 5 } & Normal & 1 & 0 & 18 & 19 \\
\hline \multirow{2}{*}{ Total } & 17 & 20 & 23 & 60 \\
\hline
\end{tabular}

Table 3 Provides information on cross tabulation between stunting and child development. According to the above table, it is found that there are 18 children in the normal or nonstunting category, all experiencing proper development. Meanwhile, there are 19 children in very short category, 13 of which have a deviating development.

Table 2.2 Chi-square Test between Stunting and Child Development

Asymptotic

Significance (2-

\begin{tabular}{lccr} 
& Value & df & \multicolumn{2}{c}{ sided) } \\
\hline Pearson Chi-Square & $52,884^{\text {a }}$ & 4 &, 000 \\
\hline Likelihood Ratio & 59,970 & 4 &, 000 \\
\hline Linear-by-Linear Association & 35,466 & 1 &, 000
\end{tabular}

$\mathrm{N}$ of Valid Cases
a. 0 cells $(0,0 \%)$ have expected count less than 5. Minimum expected count is 5,38. 


\section{STRADA Jurnal Ilmiah Kesehatan}

DOI: $10.30994 /$ sjik.v9i2.396

Sig Value according to chi-square test based on linear-by-linear of 0,000. (The selection of significance value on linear-by-linear due to ordinal scale variable). This value is smaller than 0,05 , offering the conclusion that there is a significant correlation between stunting and child development.

Table 2.3 Cross Tabulation between Psychosocial Stimulation and Child Development

\begin{tabular}{llcccc}
\hline & & \multicolumn{3}{c}{ Development } & \\
\cline { 2 - 5 } & & Deviating & Worrying & Optimal & Total \\
\hline $\begin{array}{l}\text { Psychosocial } \\
\text { stimulation }\end{array}$ & Rarely & 5 & 4 & 0 & 9 \\
\cline { 2 - 6 } & $\begin{array}{l}\text { Occasiona } \\
\text { lly }\end{array}$ & 6 & 8 & 0 & 14 \\
\cline { 2 - 6 } & Often & 6 & 7 & 7 & 20 \\
\cline { 2 - 6 } & Always & 0 & 1 & 16 & 17 \\
\hline Total & & 17 & 20 & 23 & 60 \\
\hline
\end{tabular}

Table 13 provides information on cross tabulation between psychosocial stimulation and child development. Based on the table, it is established that 16 children who are always provided with psychosocial stimulation has an optimal development. Meanwhile, 5 children who rarely experience psychosocial stimulation have a deviating development.

Table 2.4 Chi-square Test between Psychosocial Stimulus and Child Development

Asymptotic

Significance (2-

\begin{tabular}{lccc} 
& Value & df & sided) \\
\hline Pearson Chi-Square & $37,482^{\text {a }}$ & 6 &, 000 \\
\hline Likelihood Ratio & 47,994 & 6 &, 000 \\
\hline Linear-by-Linear Association & 26,570 & 1 &, 000
\end{tabular}

$\mathrm{N}$ of Valid Cases 60

a. 6 cells $(50,0 \%)$ have expected count less than 5. Minimum expected count is 2,55.

Sig. Value according to chi-square test based on linear-by-linear of 0,000 . (The selection of significance value on linear-by-linear due to ordinal scale variable). This value is smaller than 0,05 , which is conclusive that there is a significant correlation between psychosocial stimulation and child development.

\section{Multivariate Test}

Multivariate test in this study uses logistic regression test. Logistic regression analysis is conducted to determine the influence of independent variables on the dependent variables, partially or individually, as well as simultaneously or consecutively. The first logistic regression analysis is logistic regression of the influence of stunting and psychosocial stimulation on child development. 
STRADA Jurnal Ilmiah Kesehatan

DOI: $10.30994 /$ sjik.v9i2.396

ISSN: 2252-3847 (print); 2614-350X (online)

Vol.9 No.2 November 2020 Page.906-916

Table 3.1 Logistic Regression Test on the Influence of Stunting and Psychosocial Stimulation on Child Development.

\begin{tabular}{lcllll}
\multicolumn{1}{c}{ Model } & $\mathbf{- 2}$ Log Likelihood & Chi-Square & Df & Sig. \\
\hline Intercept Only & 100,096 & & & \\
\hline Final & 33,415 & 66,681 & 5 &, 000 \\
\hline Link function: Logit. & & & &
\end{tabular}

Significance value based on the result of logistic regression test is 0,000 . This value is higher than 0,05, which is conclusive that stunting and psychosocial stimulation have a significant impact on child development.

Table 3.2 Logistic Regression Partial Test on the Effects of Stunting and Psychosocial Stimulus on Child Development.

\begin{tabular}{|c|c|c|c|c|c|c|c|c|}
\hline & \multirow[b]{2}{*}{$\begin{array}{l}\text { Estimat } \\
\text { e }\end{array}$} & \multirow[b]{2}{*}{$\begin{array}{l}\text { Std. } \\
\text { Error }\end{array}$} & \multirow[b]{2}{*}{ Wald } & \multirow[b]{2}{*}{ df } & \multirow[b]{2}{*}{ Sig. } & \multicolumn{2}{|c|}{$\begin{array}{l}95 \% \text { Confidence } \\
\text { Interval }\end{array}$} \\
\hline & & & & & & & $\begin{array}{l}\text { Lower } \\
\text { Bound }\end{array}$ & $\begin{array}{l}\text { Upper } \\
\text { Bound }\end{array}$ \\
\hline \multirow[t]{2}{*}{$\begin{array}{l}\text { Threshol } \\
\text { d }\end{array}$} & $\begin{array}{l}\text { [development }= \\
1,00]\end{array}$ & $-8,701$ & 1,958 & 19,740 & 1 &, 000 & $-12,539$ & $-4,862$ \\
\hline & $\begin{array}{l}\text { [development }= \\
2,00]\end{array}$ & $-5,021$ & 1,552 & 10,465 & 1 & ,001 & $-8,063$ & $-1,979$ \\
\hline \multirow[t]{7}{*}{ Location } & $\begin{array}{l}{[\mathrm{kstunting}=1,00]} \\
\text { very short }\end{array}$ & $-5,718$ & 1,356 & 17,784 & 1 & ,000 & $-8,375$ & $-3,060$ \\
\hline & $\begin{array}{l}{[\mathrm{kstunting}=2,00]} \\
\text { short }\end{array}$ & $-3,526$ & 1,212 & 8,463 & 1 & ,004 & $-5,901$ & $-1,150$ \\
\hline & $\begin{array}{l}{[\text { kstunting }=3,00]} \\
\text { normal }\end{array}$ & $0^{\mathrm{a}}$ & . & . & 0 & . & . & \\
\hline & $\begin{array}{l}\text { [psyc=2,00] } \\
\text { rarely }\end{array}$ & $-4,029$ & 1,499 & 7,226 & 1 & ,007 & $-6,967$ & $-1,091$ \\
\hline & $\begin{array}{l}\text { psyc }=3,00] \\
\text { Occasionally }\end{array}$ & $-4,161$ & 1,397 & 8,868 & 1 & ,003 & $-6,900$ & $-1,423$ \\
\hline & $\begin{array}{l}\text { [psyc }=4,00] \\
\text { often }\end{array}$ & $-3,301$ & 1,337 & 6,092 & 1 & ,014 & $-5,922$ &,- 680 \\
\hline & $\begin{array}{l}\mathrm{psyc}=5,00] \\
\text { always }\end{array}$ & $0^{\mathrm{a}}$ & . & . & 0 & . & . & \\
\hline
\end{tabular}

Logistic regression partial test is conducted to determine how stunting variable partially influences child development. Significance value for stunting variable in the code 1 , which is for children with very short status and code 2 for children with short status, are 0,00 and 0,004 respectively. This value is lower than 0,05 , which is conclusive that individually, stunting variable has a significant influence on child development. Logistic regression coefficient in stunting code 1 and code 2 have negative values, where this value can be interpreted that children categorized as very short and short have a higher chance of having a worrying or deviating growth than normal children (non-stunting).

Significance values for psychosocial stimulation variable code 2 (children rarely receive stimulation), psychosocial stimulation variable code 3 (children occasionally 


\section{STRADA Jurnal Ilmiah Kesehatan}

DOI: $10.30994 /$ sjik.v9i2.396

ISSN: 2252-3847 (print); 2614-350X (online)

Vol.9 No.2 November 2020 Page.906-916

receive stimulation), and psychosocial stimulation variable code 4 (children often receive stimulation) are 0,007, 0,003, and 0,014, respectively. This value is lower than 0,05 , which is conclusive that individually, psychosocial stimulation variable has a significant influence on child development. Logistic regression coefficient on psychosocial stimulation variable code 2 (children rarely receive stimulation), psychosocial stimulation variable code 3 (children occasionally receive stimulation), and psychosocial stimulation variable code 4 (children often receive stimulation) has a negative value, which can be interpreted that children who rarely or occasionally receive psychosocial stimulation have a higher chance of undergoing a worrying or deviating development compared to children who often receive psychosocial stimulation.

\section{DISCUSSION}

\section{The Effects of Stunting on the Development of Children Between the Ages of 2-6 Years Old.}

Chronic malnutrition indicator concluding a long period of malnutrition is called stunting. Malnutrition in the first three years is established to be influential to brain development. (Georgieff MK., 2007). Brain development in children with malnutrition sees structural and functionality changes, in the forms of lower myelin, lower cortical dendrite in the medulla spinalis, higher mitochondria in neurons and nerves, as well as a neurotransmitter synapses reduction in relation with motor movement mechanism (Udani PM., 1992). Cerebellum is the part of a brain that serves as a center for motor movement coordination and it is most prone to the effect of malnutrition (Chang SM, Walker SP, Grantham SM, Powell CA., 2010). Stunting often is correlated with live expectancy and child development. Stunting in the early age can give rise to physical condition deficiency in the future, such as shortness, hindered learning achievement, low productivity, and higher risk for chronic diseases in the adulthood (Aguayo et al.,2015).

Based on the above explanation, it is known that, theoretically, stunting can influence child development. This is consistent with the result of this study, with a Sig. value of $\mathrm{p}=0,000$ or lower than 0,05 , indicating a significant correlation between stunting and child development between the age of 2-6 years old. The result of this study is supported by another study by Vivin ER., Eti PP. and Bhisma M. (2018), stating that it is statistically significant that stunting directly influences child development. Another study by Casale et al. (2014) is also consistent with this study, indicating that there is a strong and relevant correlation between stunting and the development of gross motor skill and fine motor skills in children. According to a study by Hizni et al. (2010), stunting increases the risk of delayed motor development in children by four times. Disrupted development is characterized by delayed nerve cell maturation, slower motor movement, slower response to environment and lower level of intelligence. According to study by Maria GP et. al. (2015), it can be concluded that there is a strong correlation between stunting and motor development of children under two years old.

A number of studies shed a light on the correlation between stunting and delayed motor and mental development on children of early age, as well as low cognitive ability and academic achievement in the late childhood. (Gibney M, Margetts B, Kearney J, Arab L., 2008). Other studies conducted by Bogale et. al, 2013; Crookston et. al., 2011; Mohd. Nasir et. al., 2012; and Ashraful Alam, Md., 2019 all indicate positive correlation between child height and development. (Perkins, J. 2017 and Ashrafaul A., et. al., 2020). 


\section{STRADA Jurnal Ilmiah Kesehatan}

DOI: $10.30994 /$ sjik.v9i2.396

ISSN: 2252-3847 (print); 2614-350X (online)

Vol.9 No.2 November 2020 Page.906-916

The Effects of Psychosocial Stimulation on the Development of Children between the Ages of 2-6 Years Old.

Cognitive ability is related with intellectual activities, such as thinking, describing, imagining, learning words, and using language. The optimization of cognitive developmentis influenced by physiological maturation, especially during the first five years (Dariyo, 2007). A child can coordinate between the movements of his/her hands, feet, and head consciously after his/her nerves and body muscles have sufficiently developed. This means that cognitive development must be synchronized with physiological maturation. Cognitive ability is one dimension in the development of a child that plays an integral role in intelligence. According to Dariyo (2007), cognitive development cannot be separated from the genetic and environment element. Family environment is one of the settings where children can obtain psychosocial stimulation. Psychosocial stimulation is defined as stimulus generated from social or psychological occurrences externally from the self, or in this case, a child that can influence his /her growth and development. Psychosocial stimulation experienced by children of 2-5 years old is measured through learning stimulation, language stimulation, physical stimulation, closeness and acceptance, role model, stimulation variation, and punishment (Dwi H.,Alfiasari, Chandriyani, 2010).

Based on the above explanation, it is known that, theoretically, psychosocial stimulationcan influence child development. This is consistent with the result of this study, with a Sig. value of $\mathrm{p}=0,000$ or lower than 0,05 , indicating a significant correlation between psychosocial stimulation and child development between the age of 2-6 years old. The result of this study is supported by Februhartanty J., et. al. (2007), stating that positive psychosocial stimulation is closely related with children health in a way that it indirectly influences the child development status. The quality of psychosocial stimulation depends on the family, society and environment. A study by Wiwin et. al. (2008), also discover how stimulation influences child development $(\mathrm{p}=0,000)$. There is a concrete correlation between psychosocial stimulation and cognitive development. This means the more psychosocial stimulation provided, the better a child cognitive development will be. Additionally, considering the influence of psychosocial stimulation on child cognitive development, it is recommended for family to provide optimal stimulation to their children. If the ability to provide stimulation is financially difficult, it is recommended for mothers to increase mother-child activities, where mothers can be more involved in caretaking (playing and going about with kids), as well as focus on expressing closeness and acceptance and becoming role models for the child. Various stimulations through five senses, such as hearing, sight, taste, olfaction, and touch, given during the early age greatly impact the development and maturation of brain. The development of children's motor skill will help them explore and practice new ability (Dwi H., 2009).

This indicates the importance of parenting for mothers regarding how to better provide stimulation to children in the most optimal way (Dwi H., 2009). The quality of caretaking environment and pattern is the stimulation given by parents and family through closeness, acceptance, role model and examples, experiences, learning and language, as well as encouraging children to develop of academic skills. Quality caretaking provided by parents through various stimulation and parent-child interaction demonstrates potential positive influence on the growth and development of a child in terms of motor, cognitive and social-emotional skills (Sri M., 2017). 


\section{STRADA Jurnal Ilmiah Kesehatan}

DOI: $10.30994 /$ sjik.v9i2.396

ISSN: 2252-3847 (print); 2614-350X (online)

Vol.9 No.2 November 2020 Page.906-916

\section{CONCLUSION}

The result of this study establishes that there is a significant correlation between stunting, in which children are categorized as short and very short, with child development between the ages of 2-6 years old. Significance values for the variables of children categorized as very short and short are 0,00 and 0,004 respectively. This value is lower than 0,05 , which is conclusive that individually, stunting variable has a significant influence on child development. Logistic regression coefficients in stunting (short and very short) have negative values, where this value can be interpreted that children categorized as very short and short have a higher chance of having a worrying or deviating growth than normal children (non-stunting).

Meanwhile, psychosocial stimulation variable also shows significant influence on the development of children between the ages of 2-6 years old. Significance values for psychosocial stimulation categorized by frequency as rarely, occasionally and often are 0,$007 ; 0,003$ and 0,014 , respectively. This value is lower than 0,05 , which is conclusive that individually, psychosocial stimulation provision variable has a significant influence on child development. Logistic regression coefficients on psychosocial stimulation variables categorized by frequency as rarely, occasionally and often have negative values, which can be interpreted that children who rarely or occasionally receive psychosocial stimulation have a higher chance of undergoing a worrying or deviating development compared to children who often receive psychosocial stimulation.

\section{REFERENCES}

Alam MA., Stephanie A., Richard, Fahim SM., Nahar B.., Das S., Shrestha B., Koshy B., Mduma E., Seidman JC., Murray-Kolb LE., Caulfield LE., Ahmed T. 2020. Impact of Early-Onset Persistent Stunting on Cognitive Development at 5 Years of Age: Results From a Multi-Country Cohort Study. Plos One 15 (1) e0227839. https://doi.org/10.1371/journal.pone.0227839.

Aguayo VM, Nina B, Kajali P. 2015. Determinants of Child Stunting in the Royal Kingdom of Bhutan: an in-Depth Analysis of Nationally Representative Data. Maternal \& Child Nutrition published by John Wiley \& Sons Ltd Maternal and Child Nutrition: 333-345.

Casale DC, Desmond, Richter L. 2014. The Association Between Stunting And Psychosocial Development Among Preschool Children: A Study Using The South African Birth To Twenty Cohort Data. Child: Care, Health and Development. Published by John Wiley \& Sons Ltd, Child: care, health and development, 40(6): 900-910.

Chang SM, Walker SP, Grantham SM, Powell CA. Early Childhood Stunting and Later Fine Motor Abilties. Journal Compilation Mac Keith Press.2010;52:831-836.

Dariyo A. 2007. Psikologi Perkembangan Anak Tiga Tahun Pertama. Bandung: PT Refika Aditama.

Februhartanty J, Usfar AA, Dianawati E, Fransisca DO, Roshita A, Fahmida U. Psycosocial care and nutritional status of children aged 6-36 months among patrilinear (Karo) and matrilinear (Minangkabau) households in Jakarta. Asia Pacific Journal Clinic Nutrition. 2007;16(2):293-300.

Gamayanti IL. Upaya Optimalisasi Fungsi Kognitif dan Psikomotrik Anak Stunting. Makalah disampaikan di: Seminar Nasional Optimalisasi Potensi Anak Stunting di Indonesia; 2 Oktober 2010; Yogyakarta. 


\section{STRADA Jurnal Ilmiah Kesehatan}

DOI: $10.30994 /$ sjik.v9i2.396

ISSN: 2252-3847 (print); 2614-350X (online)

Vol.9 No.2 November 2020 Page.906-916

Georgieff MK. Nutrition and Developing Brain: Nutrient Priorities and Measurement. Am J Clin Nutr. 2007; 85: 614S-20S.

Gibney M, Margetts B, Kearney J, Arab L. Gizi Kesehatan Masyarakat. Jakarta: EGC; 2008.

Grantham -McGregor SM, Yin BC, Cueto S, Glewwe P, Richter L, Strupp B et al. Developmental potential in the first 5 year for children in developing countries. Lancet 2007; 369(9555): 60-70.

Hastuti Dwi. 2009. Psycho Social Stimulation in Play Groups and Its Effect to Motor, Cognitive, Socio-Emotional, and Character Development Child's. Jur. Ilm. Kel. dan Kons., Januari 2009, p : 41-56 Vol. 2, No. 1.

Hastuti Dwi, Alfiasari, Chandriyani. 2010. Value of Child, Psychosocial Stimulation, and Cognitive Development of 2-5 Years Old Children in Food Insecurity Areas at Banjarnegara District, Central Java Provinc. Jur. Ilm. Kel. \& Kons., Januari 2010, p : 27-34 Vol. 3, No. 1 ISSN : 1907 - 6037.

Hizni A. Hubungan Satatus Stunted dengan perkembangan anak balita di Wilayah Pesisir Pantai Utara Kecamatan Lemah Wungkuk Kota Cirebon [tesis]. Yogyakarta: Program Pascasarjana Minat Utama Gizi dan Kesehatan Program Studi Ilmu Kesehatan Masyarakat Universitas Gajahmada; 2009.

Kementrian Kesehatan RI (2016). Pemantauan Status Gizi Dan Indikator Kinerja Gizi. Jakarta.

Maria GP., Hamam H., Indria LG. 2015. Stunting Berhubungan dengan Perkembangan Motorik Anak di Kecamatan Sedayu, Bantul, Yogyakarta. Jurnal Gizi dan Dietetik Indonesia Vol.3, No.1, Januari 2015: 10-21.

Mulyati Sri,Chundrayetti E., Masrul. 2017. Hubungan Stimulasi Psikososial dengan Perkembangan Anak Usia 3-72 Bulan di Wilayah Kerja Puskesmas Lubuk Begalung Padang. Jurnal Kesehatan Andalas. 2017; 6(2).

Ni'mah K., Nadhiroh SR. 2015. Faktor yang Berhubungan dengan Kejadian Stunting pada Balita. Media Gizi Indonesia, Vol. 10, No. 1 January-June 2015: p. 13-19.

Papalia DE, Old SW, Feldman RD. Human Development (Psikologi Perkembangan), alih bahasa oleh A. K. Anwar. Jakarta: Kencana; 2008.

Pemerintah Kota Kediri. 2018. Genbest tumbuhkan Kesadaran dan Kepedulian Generasi Milenial di Kediri akan Permasalahan Stunting. https://www.kedirikota.go.id/p/informasi/11148722/genbest-tumbuhkan-kesadarandan-kepedulian-generasi-milenial-di-kediri-akan-permasalahan-stunting\#

Perkins, J. M., Rockli, K., Krishna, A., McGovern, M., Aguayo, V. M., \& Subramanian, S. V. (2017). Understanding the Association between Stunting and Child Development in Low- and Middle-Income Countries: Next Steps for Research and Intervention. Social Science \& Medicine, 193, 101-109. https://doi.org/10.1016/j.socscimed.2017.09.039.

Rahmawati VE., Pamungkasari EP., Murti B. 2018. Determinants of Stunting and Child Development in Jombang District. Journal of Maternal and Child Health, 3(1): 6880 https://doi.org/10.26911/thejmch.2018.03.01.07.

Restivo L, Ferrari F, Passino E, Sgobio C, Bock J, Oostra BA, et al. Enriched environment promotes behavioral and morphological recovery in a mouse model for the fragile X syndrome. PNAS, [Internet]. 2005. [citied 2012 August 01]; 102: 11557-62. Available from: http://www.pnas.org 


\section{STRADA Jurnal Ilmiah Kesehatan}

DOI: $10.30994 /$ sjik.v9i2.396

ISSN: 2252-3847 (print); 2614-350X (online)

Vol.9 No.2 November 2020 Page.906-916

Santos DN, Assis AMO, Bastos ACS, Strina A, Prado MS, Barreto ML et al. Determinant of Cognitive Function on Childhood: a cohort study in a middle income context. BMC. 2008;8:202.

Teja M. 2019. Stunting Balita Indonesia dan Penanggulangannya. Info Singkat Kajian Singkat Terhadap Aktual dan Strategis, Pusat Penelitian Bdan Keahlian DPR RI. Vol.XI, No.22/II/Puslit/November/2019. http://puslit.dpr.go.id. ISSN 2088-2351.

Udani PM. Brain and Various Facets of Child Development. Indian J Pediatrict. 1992,59: 165-186.

Walker WA, Watkins JB, Duggan C. Nutrition in Pediatrics. London: BC Decker Inc; 2003.p.388-393, 540-54

Wiwin M, Setijaningsih T, Winarni S. Pengaruh stimulasi psikososial terhadap Perkembangan Anak Sebagai Tindak Lanjut DDTKA Masal Pasca Pencatatan Rekor Muri Di Kota Blitar. Malang: Repository Program Studi Keperawatan Blitar, Poltekkes Depkes Malang; 2008. 